\title{
Separation of YbdN Bioactive Protein from Bacillus subtilis Isolated from the Red Sea algae Sargassum sp. with Bioactivity against Antibiotic Resistant Bacterial Pathogens
}

\author{
M. T. Jamal and M.S. A. Mudarris \\ Faculty of Marine Science, King Abdulaziz University, \\ P.O.Box 80207 Jeddah 21589, Saudi Arabia
}

\begin{abstract}
Hundreds of bacterial isolates from Red Sea Jeddah coast included seawater, sediments, algae (Halimeda sp., Sargassum sp), sponges (Siphonochalina sp., Leucetta chgosensis), sea cucumber, (Holothuria atra), star fish (Acanthaster planci), mangrove (Avecenia marina) roots, sea anemone, (Heteractis magnifica), and jelly fish. One bacterial culture of them isolated from algae Sargassum $\mathrm{sp}$ identified as B. subtilis produced $\mathrm{YbdN}$ protein which known as antimicrobial compound against Methicillin-Resistant Staphylococcus aureus, Vancomycin-Resistant Enterococci and Listeria monocytogenes. B. subtilis production of $\mathrm{YbdN}$ protein was best in Colombia broth with pieces of synthetic polyurethane sponge at $28^{\circ} \mathrm{C}$ incubation temperature for 7 days, and shaking at $210 \mathrm{rpm}$.
\end{abstract}

Keywords: Red Sea; Algae; Pathogens; Bacteria; Bioactive Protein; Bacillus subtilis

\section{Introduction}

Natural and effective antibacterial compounds against antibiotic-resistant as well as new bacterial pathogens are continually sought after for application in human and veterinary medicine (Finch et al., 2002). These natural products may exert their effect on bacterial cell membranes and/or specific protein targets (Stone and Williams, 1992; Butler, 2004; $\&$ Koehn and Carter, 2005). They normally have complicated structure that makes their artificial synthesis difficult and often expensive. This gives added advantage to the naturally occurring compounds if they could easily be extracted and purified in good quantities and with reasonable cost. 
Marine organisms have been used as source of many useful natural compounds. The genus Bacillus is widely distributed in marine environment and produces a variety of useful products (Cherif et al., 2001; and Aria et al. 2003). Members of this genus as well as many others need to be studied under varying culturing scenarios to determine conditions conducive to production of useful natural compounds. This is particularly important in the light of the ever spreading of antibiotic resistance by many strains of bacterial pathogens. These include methicillin-resistant Staphylococcus aureus (MRSA) and vancomycinresistant enterococci (VRE) which often cause post surgery infection (Richards et al., 2005). Consequently, this study was undertaken to recovery and characterization of compounds with effectiveness against antibiotic-resistant bacteria from Red Sea.

\section{Materials and Methods}

\section{Bacterial Culture}

The samples included the sea algae (Halimeda sp., Sargassum sp.), sponges (Siphonochalina sp., Leucetta chgosensis), sea cucumber, (Holothuria atra), star fish (Acanthaster planci), sea anemone, (Heteractis magnifica), jelly fish, mangrove (Avecenia marina) roots, sediment and seawater. With the exception of sediment and seawater, the samples were placed into $10 \mathrm{ml}$ volumes of sterile $\left(121^{\circ} \mathrm{C} / 15 \mathrm{~min}\right)$ seawater in plastic bottles, transported on ice to the laboratory. Sediment and seawater were transported in pre-sterilized plastic bottles. Analyses were carried out at King Abdulaziz University, (Jeddah) Saudi Arabia and Heriot Watt University laboratory (Edinburgh) Scotland. Subsamples, $1.0 \mathrm{~g}$ or $1.0 \mathrm{ml}$ as appropriate, were transferred to $10 \mathrm{ml}$ volumes of sterile seawater, and shaken vigorously for $\sim 5 \mathrm{~min}$ to dislodge micro-organisms. Then, 10-fold dilution were prepared, and 10 $\mu 1$ of each dilution spread over plates of marine agar (2216E, Difco), tryptone soya agar (TSA) (Oxoid) supplemented with $1 \% \mathrm{NaCl}$ (= TNA), diagnostic sensitivity test agar (DST) (Oxoid), and an equi-mixture of marine $2216 \mathrm{E}$ agar and TSA. Media were incubated at room temperature for up to 14 days. Then, colonies representative of each colony type were streaked and re-streaked on fresh media to obtain pure cultures. Examination for inhibitory activity was performed on 376 bacterial 
strains against MRSA 9551 and MRSA J2407 and against VRE 788 and VRE 1349 (courtesy of S.G.B. Amyes, University of Edinburgh), Listeria monocytogenes National Collection of Type Cultures (NCTC), Colindale, London 10357 and 7973), Escherichia coli (laboratory culture), Pseudomonas aeruginosa (laboratory culture) and Salmonella enteritidis (laboratory culture) by using cross streaking method (Robertson et al., 2000). Each marine culture were streaked at right angles across lines of inocula of the pathogens, and incubated for $24 \mathrm{~h}$ at $37^{\circ} \mathrm{C}$. Any production of antimicrobial compounds was indicated for each isolate by showing interruption spots of inhibition in otherwise continuous growth lines of the pathogens. The bioactive isolated marine cultures were identified by examination of key phenotypic traits (Sneath, 1986 ) and by $16 \mathrm{~S}$ rRNA sequencing. Thus, the cultures were grown for $24 \mathrm{~h}$ at $28^{0} \mathrm{C}$ in tryptone soya broth supplemented with $1 \% \mathrm{NaCl}$ (TNB), and the cells harvested by centrifugation for $10 \mathrm{~min}$ at $4^{\circ} \mathrm{C}$ and $5000 \times \mathrm{g}$. The DNeasy tissue kit (Qiagen) and protocol was used to extract and purify the total DNA from animal tissues. Sequencing was carried out using universal primers amplifying a $1500 \mathrm{bp}$ region of the 16S rRNA gene (9F: 5'-GAGTTTGATCCTGGCTCAG-3', 1492R: 5'GGYTACCTTGTTAACGACTT-3') by MWG-Biotech. For identification of isolates, the 16S rRNA gene sequences were compared to data base using the basic alignment search tool (BLAST) (Altschul et al., 1990).

\section{Determination of Inhibitory Activity}

Only one out of 376 isolates was found to produce growth inhibitory compound. Routine and gene sequencing tests showed the isolate to be Bacillus subtilis (see Results and Discussion below). The best growth was obtained in Columbia broth (Oxoid) with pieces of sponge, when incubated at $28^{\circ} \mathrm{C}$ for up to $7 \mathrm{~d}$ with shaking at $210 \mathrm{rpm}$. The bioactive compound was extracted in supernatant following centrifugation at $10,000 \times \mathrm{g}$ for $15 \mathrm{~min}$ at $4^{\circ} \mathrm{C}$, and filtration through $0.22 \mu \mathrm{m}$ Millipore Millex porosity filters. Inhibitory activity was assessed against the bacterial cultures listed previously. This was carried out using well diffusion (Jack et al., 1995) and by disc diffusion using $6 \mathrm{~mm}$ diameter Whatman No. 1 filter paper discs, which were impregnated with $110 \mu 1$ volumes of the filtrate. 


\section{Isolation, Purification and Characterization of the Inhibitory Compounds}

The growth conditions mentioned above were used to give the largest volume of bioactive supernatant. The filtered supernatant was concentrated by using a special molecular weights tube filter (Amicon Ultra $-15 ; 10,000$ MWCO) which collect all protein or molecules with molecular weights higher than $10 \mathrm{kDa}$. The supernatant concentrated after adding phosphate buffered saline (PBS; Oxoid; pH 7.4). Thereafter, concentrated proteins were applied to a Superose 12 HR 10/30 columns (Pharmacia, LKB) for gel filtration at a flow rate of $30 \mathrm{ml} / \mathrm{h}$ in PBS. The automatic fractions collector gave many 1-ml fractions; one of them was found to contain the inhibitory activity, for which it was tested as mentioned before.

Four milliliters of active gel filtrate each from a gel run were applied to a FPLC-MonoQ anion exchange column and eluted with a 0 to $1 \mathrm{M}$ $\mathrm{NaCl}$ gradient in phosphate buffer $(\mathrm{pH} 7.0)$ at a flow rate of $1 \mathrm{ml} \mathrm{min}^{-1}$. All the fractions were tested to assess the activity against different strains of MRSA, VRE and Listeria monocytogenes.

To determine the molecular weight of the active component, denaturing polyacrylamide gel electrophoresis (SDS_PAGE) was used (Laemmli, 1970). Continuous gel was used with 10\% concentration, and $15 \mu \mathrm{l}$ of chilled acetone-precipitated active component were loaded together with $5 \mu \mathrm{l}$ volumes of SDS/PAGE molecular weight markers (Bio-Rad, Low range) (diluted 1:20 in SDS reducing sample buffer). Thereafter, electrophoresis was run (Bio-Rad, 1000/1500) at $100 \mathrm{~mA}$ for $30 \mathrm{~min}$ and $150 \mathrm{~mA}$ for $60 \mathrm{~min}$. Gel was stained with Coomassie brilliant blue (CBB; 10.4\% R-250: Sigma).

The protocols for MALDI-TOF-MS were carried out as per the technical manual provided by the manufacturer Amersham Pharmacia Biotech with minor modifications to identify the protein.

The effect of different physiochemical factors on the inhibitory activity of the supernatant was tested employing gel diffusion technique. Parameters tested included: Temperature $\left(0-121^{\circ} \mathrm{C}\right.$ for $\left.30 \mathrm{~min}\right), \mathrm{pH}$ (1-14 at $4^{\circ} \mathrm{C}$ for $24 \mathrm{~h}$ ), $0.5 \mathrm{mg} \mathrm{ml}^{-1} \alpha$ - and $\beta$-amylase (Sigma), protease $\mathrm{K}$ (Sigma), pronase (Sigma), trypsin (Sigma), and Tween 20, 40, 60 and 80. 


\section{Results and Discussion}

One bacterium out of 376 isolates was found to produce the bioactive compound. Based on physical, biochemical and gene sequencing, the isolate was identified as Bacillus subtilis (100\% similarity by $16 \mathrm{~S}$ rRNA gene sequencing). Inhibitory activity was demonstrated on MRSA 9551, MRSA J2407, VRE 788, VRE 1349 and L. monocytogenes (NCTC 7973 and NCTC 10357). The assignment of the bioactive compound to $B$. subtilis is easily accomplished by cross streaking. This technique could initially be readily used to reveal if such a compound is produced and to distinguish the bioactive compound producing isolate. For maximal growth and production of this extracellular product, Columbia broth provided with pieces of synthetic polyurethane sponge, and shaking at $210 \mathrm{rpm}$ is recommended. The production was reduced when culturing is carried out in Columbia broth without shaking or in other type growth media.

The beneficial effect of shaking may be due to the even distribution of the isolate throughout the broth medium or due to added aeration. The sponge pieces definitely provide more surface area and promote biofilm formation (Brindle et al., 1998). They also enhance the production of the bioactive protein (Jamal et al., 2006).

The physiochemical factors provide evidence that the bioactive compound is a protein; as it was affected by either Tween 20, 40, 60 or 80 , or $\alpha$ - or $\beta$-amylase, it was sensitive to protease $\mathrm{K}$, pronase and trypsin and it was not affected by heating to $40^{\circ} \mathrm{C}$ or by exposing to $\mathrm{pH}$ of value range of 5-14. Also, its absorbance is maximal at $280 \mathrm{\eta m}$ wave length (Fig. 1a), and only fractions with A 280 maxima showed inhibitory activity (Fig. 1b).

Molecular weight determination showed a single band in the bioactive fraction corresponding to $30.7 \mathrm{kDa}$ (Fig. 1c), which was inhibitory to the cultures of MRSA and L. monocytogenes (Fig. 1d). Also, one of the filtrate of ion-exchange chromatography showed the same single band of $30.7 \mathrm{kDa}$ on the electrophoresis after testing bioactivity at $400 \mathrm{mM} \mathrm{NaCl}$ (Fig. 2 a-c). Identification of the purified 
protein By MALDI-TOF-MS-PRO analysis and comparison with the NCBI database showed that the bacteriocin is homologous with YbdN protein. This protein is known to be produced by B. subtilis, by E. coli O157:H7 EDL933, and by B. licheniformis. Therefore, the extracellular product extracted from $B$. subtilis is the $\mathrm{YbdN}$ protein and with antimicrobial function against MRSA, VRE and L. monocytogenes.

It is known that the marine bacteria bacilli have long been associated with the production of antibacterial compounds. These bacteria are widely distributed in the environment, and are used in the biotechnology industry to manufacture enzymes, antibiotics, biochemical's and consumer products (Erickson, 1976; Alexander, 1977; Eveleigh, 1981; and Austin, 2001). Another bacteriocin, (thuricin 7), with a molecular weight of $11.6 \mathrm{kDa}$ is produced by $B$. thuringiensis, and is effective against B. cereus, Streptococcus pyogenes and L. monocytogenes (Cherif et al., 2001). Antimicrobial compounds which are effective against MRSA and VRE were also produced by B. licheniformis strain EI-34-6, which was isolated from the surface of marine alga (Yan et al., 2003).

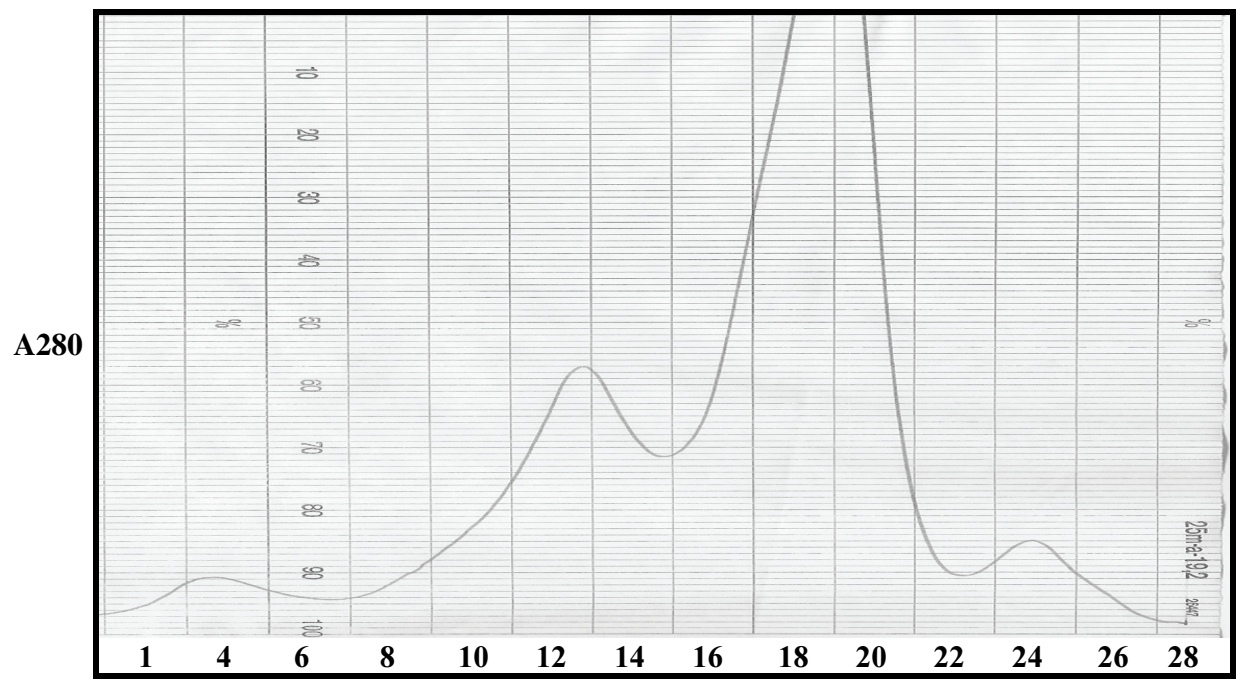

Fig. 1(a). A280 profile of the supernatant from gel filtration. 


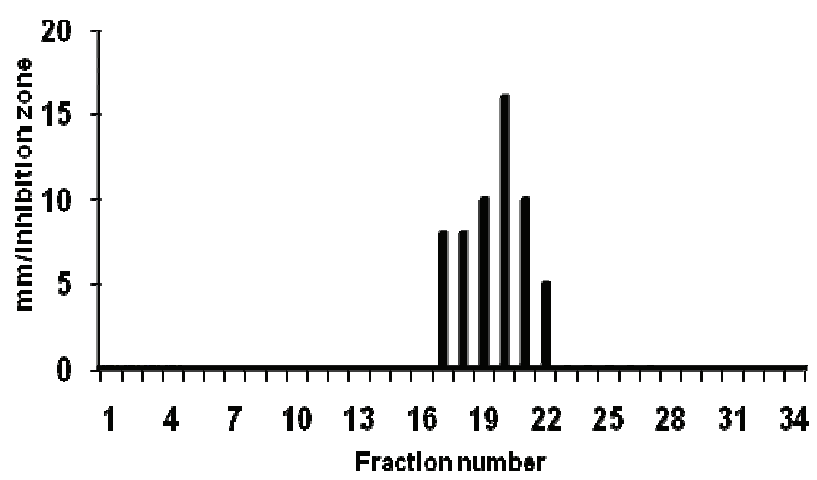

Fig. 1(b). Inhibitory profile of gel filtration fraction 1 to 34 showing inhibitory activity corresponding to the A280 profile in Fig. 1(a).

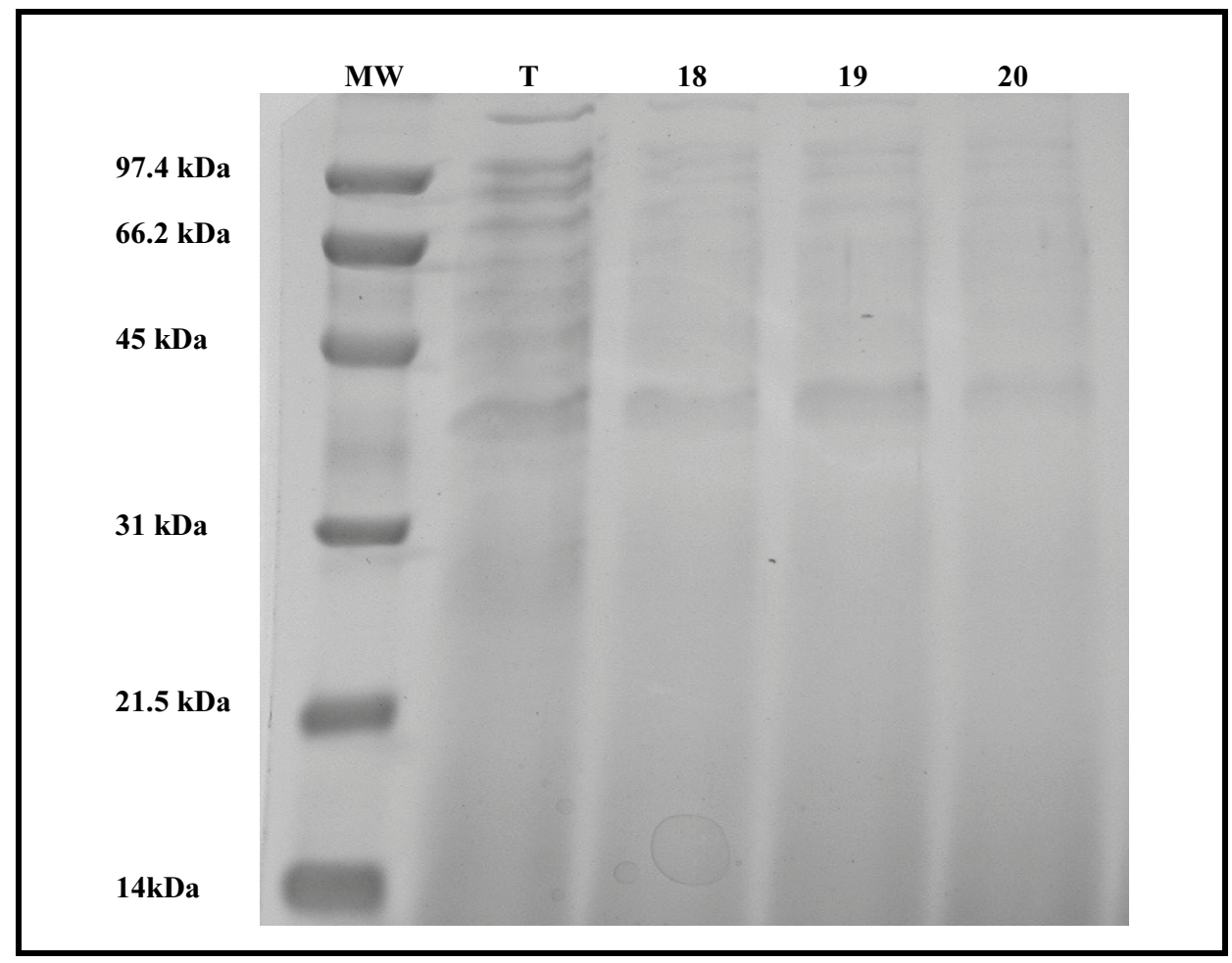

Fig. 1(c). Lanes 18-20, SDS-PAGE analysis of the active antibacterial fractions after gel filtration. Lane $T$ contains the supernatant before fractionation. MW contains the molecular weight markers. 


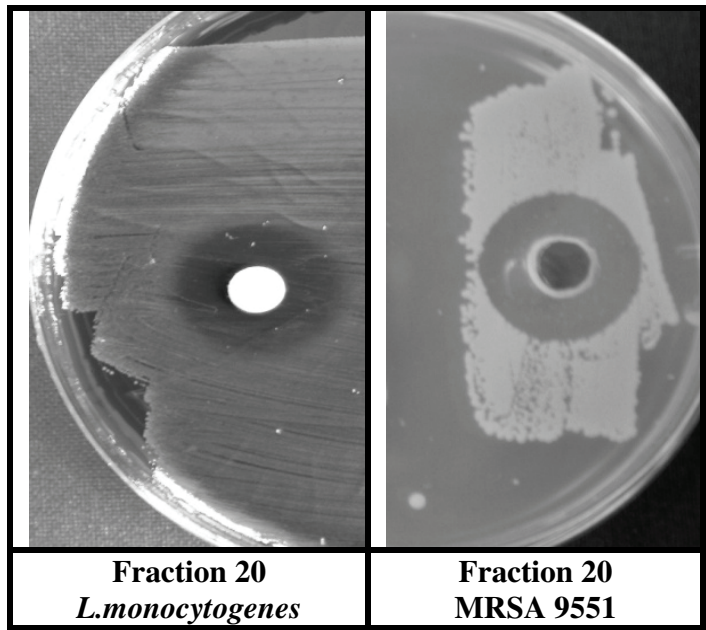

Fig. 1(d). Zones of inhibition resulting from fraction 20.

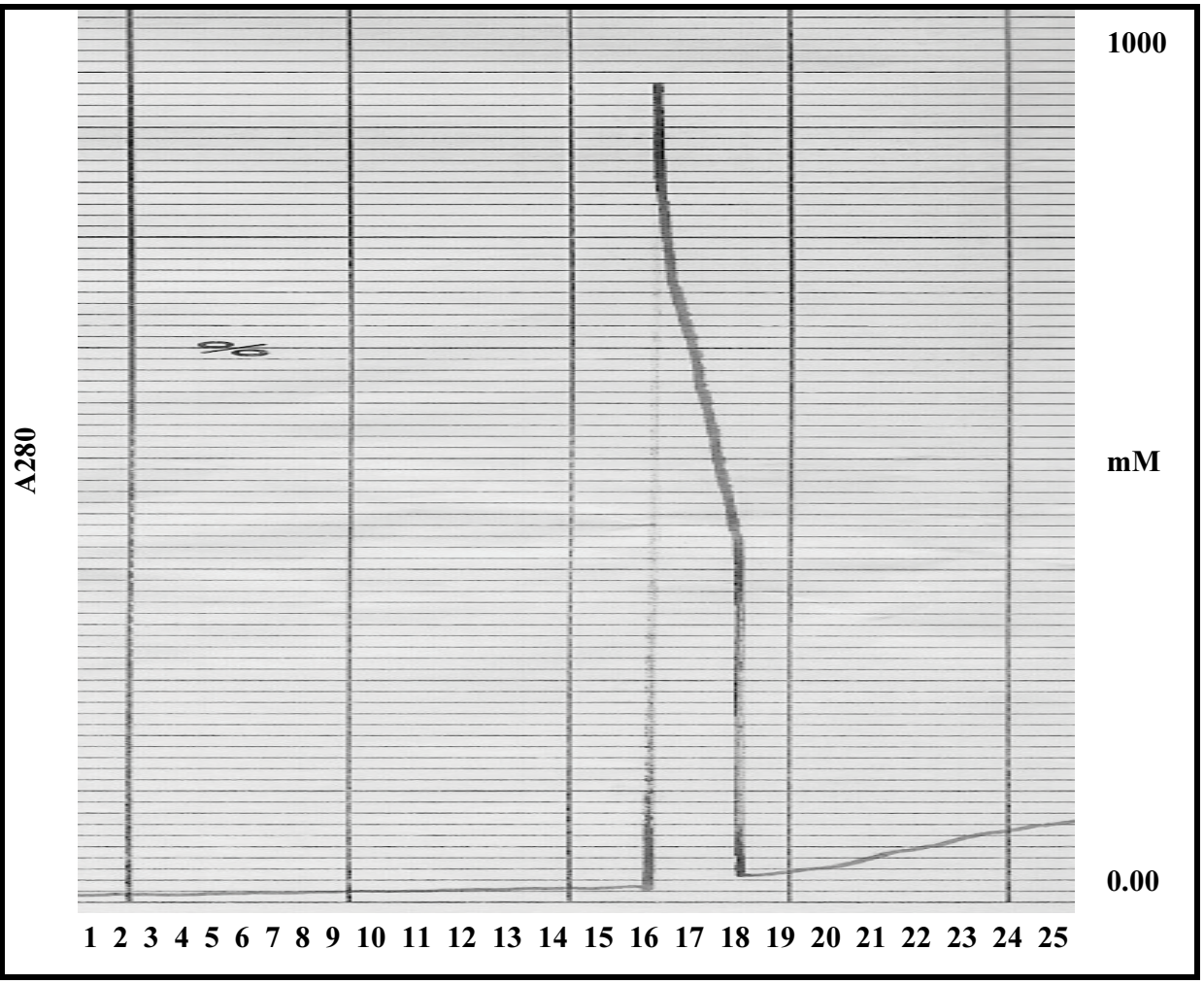

Fig. 2(a). A single protein peak that eluted at $64 \%$ to $72 \%(\mathrm{wt} / \mathrm{vol}) \mathrm{NaCl}$ was revealed by anion exchange chromatography of the active gel filtration fractions (Fig. 1). 


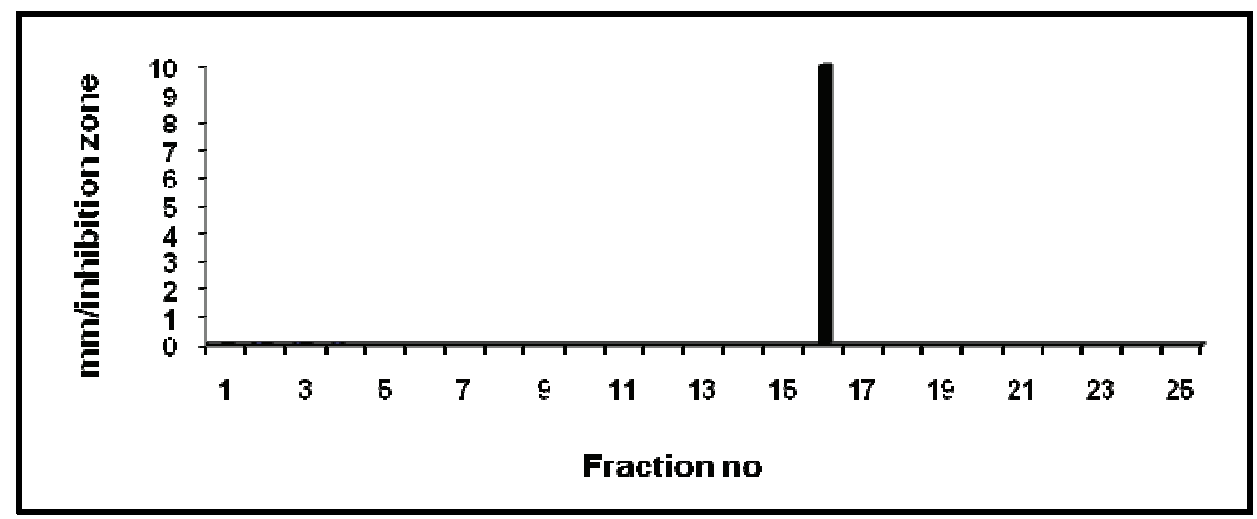

Fig. 2(b). Inhibitory profile of ion-exchange fractions corresponded with the protein peak of Fig. 1(a).

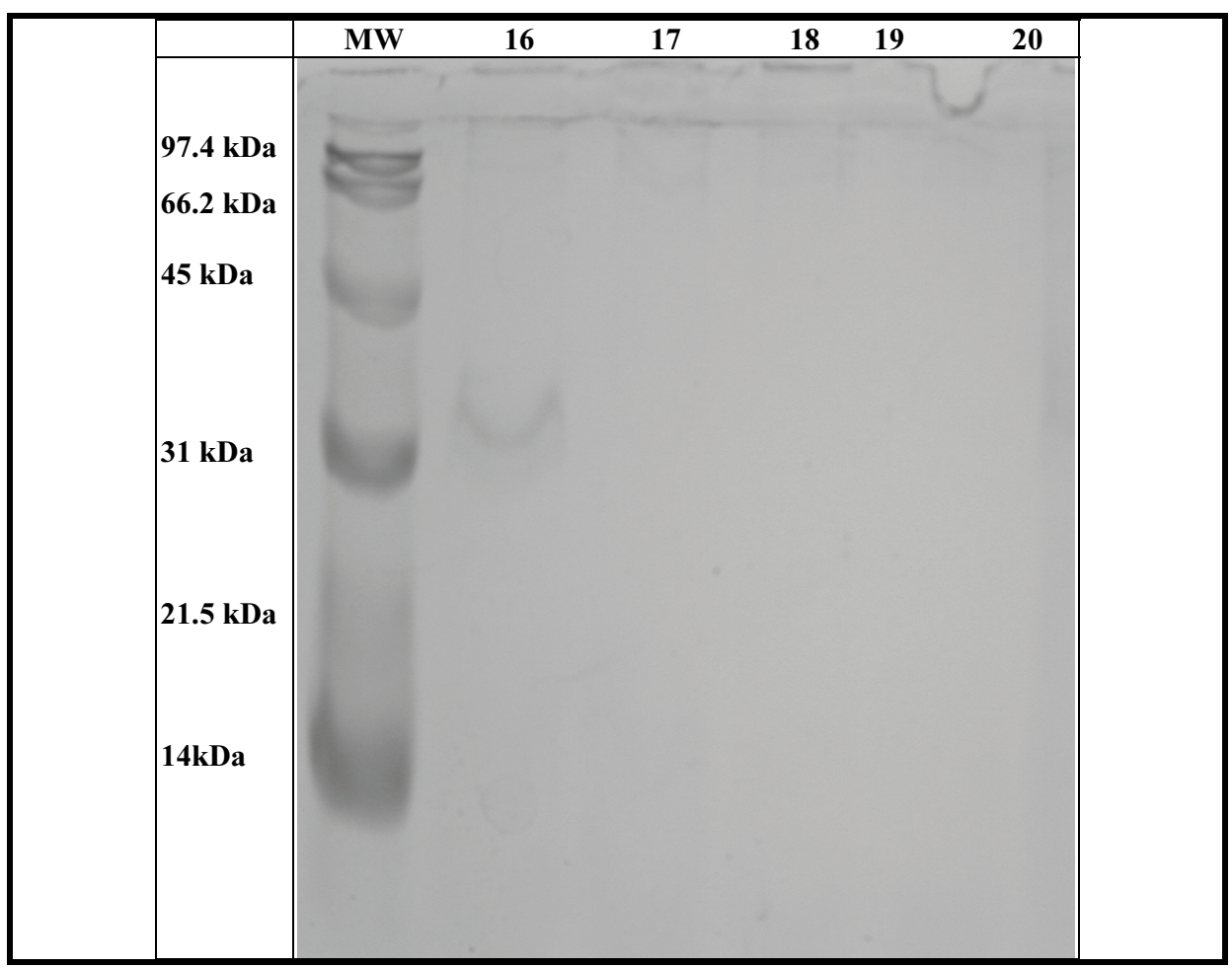

Fig. 2(c). SDS-PAGE analysis after anion-exchange of fractions 16 to 20, with inhibitory activity in fraction 16. Lane MW contains the molecular weight markers. 


\section{Conclusions}

- An extracellular product with antimicrobial activity was extracted from broth culture of Bacillus subtilis in Columbia broth.

- The extracellular product was identified as YbdN protein and demonstrated inhibitory effect on the growth of methicillin-resistant Staphylococcus aureus, vancomycin-resistant Entrococcus, and Listeria monocytogenes.

- Best production of the protein was achieved when the broth culture was provided with synthetic polyurethane sponge pieces with culture shaking.

\section{References}

Alexander, M. (1977) Introduction to Soil Microbiology, New York: John Wiley.

Altschul, S.F., Gish, W., Miller, W., Myers, E.W. and Lipman, D.J. (1990) Basic local alignment search tool. J. Mol. Biol. 215: 403-410.

Aria, A., Hata, M., Ogura, M. and Tanaka, T. (2003) Inhibition of Bacillus subtilis aprE expression by linchomysin at the posttranscriptional level through inhibition of ppGpp synthesis. J. Biochem. 134: 691-697.

Austin, B. (2001) Novel pharmaceutical compounds from marine bacteria. In: Recent Advances in Marine Biotechnology, Vol. 6. Bio-organic Compounds: Chemistry and Biomedical Applications, R. Nagabhushanam, M. Fingerman, (ed.) (New Delhi: Oxford and IBH), pp: $1-19$.

Brindle, K., Stephenson, T. and Semmens, M.J. (1998) Nitrification and oxygen utilisation in a membrane aeration bioreactor. J. Membr. Sci. 144: 197-209.

Butler, M.S. (2004) The role of natural product chemistry in drug discovery. J. Nat. 12: 21412153.

Cherif, A., Ouzari, H., Daffonchio, D., Cherif, H., Ben Slama, K., Hassen, A., Jaoua, S. and Boudabous, A. (2001) Thuricin 7: a novel bacteriocin produced by Bacillus thuringiensis BMG1.7, a new strain isolated from soil. Lett. Appl. Microbiol. 32: 243-247.

Erickson, R.J. (1976) Industrial applications of the bacilli: a review and prospectus. In: D. Schlesinger, (ed.), Microbiology. Washington, D.C.: American Society for Microbiology, pp: 406-419.

Eveleigh, D.E. (1981) The microbial production of industrial chemicals. Sci. Am. 245: 155-178.

Finch, R., Schürmann, D., Collins, O., Kubin, R., McGivern, J., Bobbaers, H., Izquierdo, J. L., Nikolaides, P., Ogundare, F., Raz, R., Zuck, P. and Hoeffken, G. (2002) Randomized controlled trial of sequential intravenous (i.v.) and oral moxifloxacin compared with sequential i.v. and oral co-amoxiclav with or without clarithromycin in patients with community-acquired pneumonia requiring initial parenteral treatment. Antimicr. Ag. Chemother. 46: 1746-1754.

Jack, R.W., Tagg, J.R. and Ray, B. (1995) Bacteriocins of Grampositive bacteria. Microbiol. Rev., 59: 171-200. 
Jamal, M.T., Morris, P.C., Hansen, R., Jamieson, D.J., Burgess, G.J. and Austinm B. (2006) Recovery and Characterization of a $30.7-\mathrm{kDa}$ Protein from Bacillus licheniformis Associated with Inhibitory Activity Against Methicillin-Resistant Staphylococcus aureus, Vancomycin-Resistant Enterococci, and Listeria monocytogenes. Marine Biotechnology, 8: 587-592.

Koehn, F.E. and Carter, G.T. (2005) The evolving role of natural products in drug discovery. Nat. Rev., 4, www.nature.com/reviews/drugdiscovery.

Laemmli, U.K. (1970) Cleavage of structural proteins during the assembly of the head of bacteriophage T4. Nature (London) 227: 680-685.

Richards, T., Pittathankel, A.A., Pursell, R., Magee, T.R. and RB, G. (2005) MRSA in lower limb amputation and the role of antibiotic prophylaxis. J. Cardiovasc. Surg., 46: 37-41.

Robertson, P.A.W., O-Dowd, C., Burrells, C., Williams, P. and Austin, B. (2000) Use of Carnobacterium sp. as a probiotic for Atlantic salmon (Salmo salar L.) and rainbow trout (Oncorhynchus mykiss, Walbaum). Aquaculture, 185: 235- 243.

Sneath, P.H.A. (1986) Endospore-forming Gram positive rodes and cocci. In: Bergey Os Manual of Systematic Bacteriology, Sneath, P.H.A. et al., (ed.) (Baltimore: Williams \& Wilkins), pp: 1104-1207.

Stone, M.J. and Williams, D.H. (1992) On the evolution of functional secondary metabolites (natural products). Mol Microbiol., 6: 29-34.

Yan, L., Boyd, K.G., Adams, D.R. and Burgess, J.G. (2003) Biofilmcross - specific induction of antimicrobial compounds in bacilli. Appl. Environ. Microbiol., 69: 3719-3727. 
فصل بروتين (YbdN) من بكتيريا Bacillus subtilis المعزولة من طحالب .Sargassum sp. من البحر الأحمر ذي فاعلية مضادة لجر اثثم ممرضة و مقاومة للمضادات الحيوية

\section{ممدوح طله جمال، و محمد سعيل مدرس}

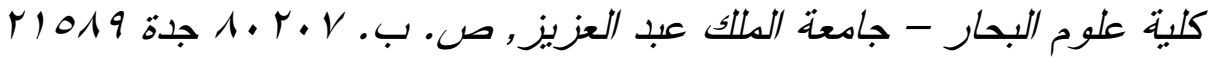
المدلكة العربية السعودية

المستخلص. من مئات المعزو لات البكتيرية من ماء وروسوبيات

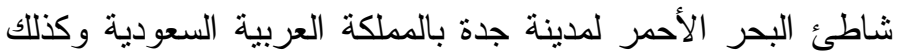

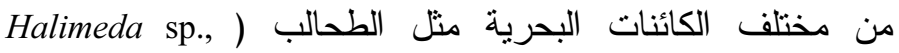
Siphonochalina sp., Leucetta (Sargassum sp. (chgosensis Avecenia (Acanthaster planci) (marina), وشقائق النعمان (Heteractis magnifica)، وسمك الجلي, وجدت معزولة بكتبرية واحدة من طحالب .Sargassum sp.

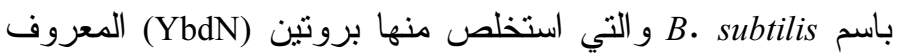
بفاعلينة المضادة لسلالات بكتيرية ممرضة للإنسان ومقاومة للمضادات الحيوية منثل : Methicillin-Resistant Staphylococcus aureus VancomycinResistant Enterococci and Listeria monocytogenes.

إن أفضل ظروف لإنتاج البروتين كانت عن طريق زراعة النوع

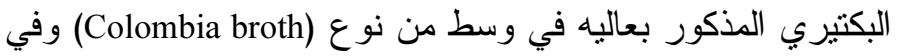
وجود قطع من اسفنج (synthetic polyurethane) في درجة ونة حرارة MN درجة مئوية لمدة سبعة أيام في حاضنة ذات الهنزاز دائري بسر عة محددة · ماب د دائرة / دقيقة. 